\title{
SOME ROMAN INSCRIPTIONS FROM BRITAIN: AMPHORA EVIDENCES
}

\author{
Pedro Paulo Abreu Funari*
}

\author{
FUNARI, P. P.A. Some Roman inscriptions from Britain: amphora evidences. Rev. do Museu \\ de Arqueologia e Etnologia, S. Paulo, 3: 121-135, 1993.
}

RESUMO: O artigo visa publicar e analisar algumas inscrições pintadas, em ânforas encontradas na Grã-Bretanha. São discutidas e estudadas em termos de suas caracteristicas históricas e paleográficas. $\mathrm{O}$ autor conclui com uma breve discussão do consumo do azeite e das azeitonas espanholas como a materialização de um estilo de vida patrocinado pelo próprio Estado.

UNITERMOS: Inscrições latinas - Ânforas romanas - Consumo de azeite.

\section{Introduction}

In the last decade, I have collected hundreds of amphora inscriptions from Britain, most of them unpublished stamps. Painted inscriptions (tituli picti) are seldom preserved and the number of new unpublished dipintos is very limited. Mark Hassal and Roger Tomlin have been in charge of the publication of inscriptions annualy in Britannia and they have published some cursive inscription on amphorae. However, Tomlin (1993) expresses a common concern by Latin epigraphists confronted with some very particular amphora inscriptions when he emphasizes that "Dressel $20<$ sc. an amphora type $>$ inscriptions I found difficult, since they are usually fragmentary and the comparative material since $\mathrm{CIL} X \mathrm{XV}$ is so scattered". In the late 1980s I published several Dressel 20 tituli picti and tituli graphio exarati (graffiti) found in the recent excavations at Vindolanda (Funari, 1991). Most were up to that moment unpublished, with the exception of a graffito published by Tomlin (1988:503) with a different reading.

(*) Departamento de História do Instituto de Filosofia e Ciências Humanas da Universidade Estadual de Campinas.
The fact is that there is still a lack of detailed studies of cursive amphora inscriptions, resulting in some underestimate of their scientific value. The aim of this paper is to publish for the first time some inscriptions and to publish anew inscriptions studied some time ago. All the inscriptions were submitted to the author by the excavators or by the scholars in charge of the archaeological material, in the case of the unpublished ones; the Alcester Dressel 20 inscription was submitted to the author by an amphora expert from the University of Southampton, Dr. David Williams. The publication of these cursive inscriptions in a single paper will enable epigraphists, amphora experts and other interested scholars to have an easier access to this evidence, as their scattered publication in different journals and books make its use considerably more difficult.

\section{A Dressel 20 dipinto from Alcester, Warwickshire (U.D.)}

An almost complete Dressel 20 Spanish oliveoil amphora was found in 1965 at Alcester, Warwickshire, U.K. All the available data on the inscription, including drawings, were provided to the author by Dr. David Williams. It bore a graffito 
and two painted isncriptions, which were published very briefly in the Journal of Roman Studies (1966:224). The original report is here fully quoted to allow a better understanding of the remarks carried out later in this paper:

"Globular amphora restored from several fragments found (59) in 1965 at Alcester. (a) A black "dipinto" in cursive letters $3 / 4$ in. high runs vertically downwards to the left of one handle and reads: CAVS. (b) a second black "dipinto" in cursive letters $1 / 4$ in. high runs down vertically from the lower junction of handle and reads: SCO.FLOS SCOM(BRI). (c) With the vessel inverted a graffito has been cut before firing near the knob of the base reading: SVRINAE/VIRILIS.

59. (a) No interpretation has been found for CAVS, recorded at Pompeii, CIL IV, 5989. In (b) FLOS SCOMBRI, "prime extract of mackerel", is well attested, e.g. CIL IV, 2576, 5679, 9397-9; XV, 4687. The mark which resembles a large $T$ on the photograph seemed on inspection to be due to chance. (c) For the "nomen" Surinus, see CIL V, 483,544 . The second name seems to be Virilis although the writer of it cut III instead of ILI. It is not clear whether the genitive case marks this vessel as the product or the property 'of Surina Virilis'".

As an early effort in studying the amphora, it was very useful but after a quarter of a century and a very comprehensive improvement in our knowledge of both Dressel 20 typology and inscriptions (Rodriguez-Almeida, 1984) it is high time to reconsider the importance of this archaeological material. Unfortunately, the available photograph of the cursive titulus, as well as the drawings of all the inscriptions are not very accurate. It could very hardly be different though, for our knowledge of Dressel 20 tituli picti was then much less detailed than it is now. It was not until the beginning of the 1970s that these amphorae and inscriptions were fully studied and understood in detail. This means that the reading was from the start doomed to at least partial failure, as it seems was the case. But from the very scantly drawing available, it is possible to propose some possible reconstructions of the epigraphic information.

\section{General remarks, typology and dating}

Spanish olive-oil Dressel 20 globular amphorae usually show a very standard pattern of painted inscriptions, refering to the weight of the vessel in Roman pounds, to the olive-oil weight in Roman pounds, to a tradesman (in capital letters) and to a control, written in cursive, relating to the consular date and other data (Rodriguez Almeida 1984:207-260). They follow a very regular pattern and we are thus sure that these tituli picti are not these well-know Spanish inscriptions. On the other hand, the graffito, written before firing in Baetica, is of a well-known type as regards the shape of the letters and its meaning. The globular body, the narrow and short neck, and the round handles favour a mid to late second century date, in agreement with its second century archaeological context in a deposit containing Samian ware ( $\mathrm{AD}$ 130-150; Antonine; $A D$ 155-190) and mortaria (AD 100-400; AD 240-400; AD 260-300).

\section{Graffito}

This is a very clear inscription in two lines: SVRINAE/VIRIIIS. All the letters are clearly written (contraJRS 1966:224; cf. CIL XV, 3616) and they refer probably to a Surina Virilis. The genitive perhaps does not refer to an owner or producer of the vessel (officinator), as is usually thought of genitive case inscriptions on vessels (Dressel 1978:212; Rodriguez-Almeida 1984: 254), but it could refer simply to the owner of the inscription itself, meaning thus "graffito of Surina Virilis" (titulus Surinae Virilis). Of course, this is an unverifiable supposition, but is based on the existance of graffiti with names in the genitive case written on the walls and that are difficult to explain, as e.g. CIL IV 8813, 889, and 8957.

\section{Painted inscriptions}

There are two black dipintos, published originally as CAVS and SCO.FLOS SCOM(bri). The former, written in capital letters, shows four letters, probably CXVS. The second letter could not be an $A$, for it would thus be difficult to explain the right apex (FIGURE 1). It seems more reasonable to suppose that it is an $\mathrm{X}$ as in CIL XV, 4340 and Rodriguez-Almeida (1979:921-2, no. $31 \mathrm{~A})$. It could thus refer to a number, CXVS(emis) or CXVI or to the number CXV, followed by SO. This number, which was probably written in Britain (Hamp, 1975), could refer to the number of amphorae, or to a sequential number relating to the vessel. Perhaps it could refer 
FUNARI, P. P. A. Some Roman inscriptions from Britain: amphora evidences. Rev. do Museu de Arqueologia e Etnologia, S. Paulo, 3: 121-135, 1993.

to the weight of a possible product that was put inside the vessel after the olive-oil was removed from it.

The cursive titulus that runs down vertically from the lower junction of one handle was read as SCO.FLOS.SCOM(bri) and translated as "prime extract of mackerel". But the letters are completely misrepresented by the original drawing and the proposed reading is untenable on both paleographic and semantic grounds. Indeed, the shapes of the proposed letters are completely without parallels, as FIGURE 2 shows clearly. The only possible recognizable letter is $C$, the others being too speculative. And last but not least, although the photograph is not at all clear, it seems that the last visible letter at the right is an $S$ or a $T$, adding to the difficulty of interpreting the inscription paleographically. On semantic grounds, the proposed reading is even less convincing, for the following reasons:

1. The ordinary word order seems to be flos scombri, not the other way round (cf. CIL IV, 2574 to 78), although we find some garum scombriflos (as CIL XV 4687, 4692, 4697), but always preceded by "fish sauce" (garum);

2. The ordinary abbreviation used is $f$ for flos (CIL XV, 4722; IV, 2574, inter alia, cf. Zevi, 1966);

3. The repetition of $s c o$ is unparalleled;

4. The use of stops, as after sco and flos, is most unusual in these inscriptions;

5. These inscriptions are written with capital letters, not with cursive as here (CIL XV, 46874731; CIL IV, 2562-2738);

6. As scomber is a mackerel, and so a fish, there could be no reason to refer to "the best kind" (=flos) of mackerel, for it was not the fish that was very good,
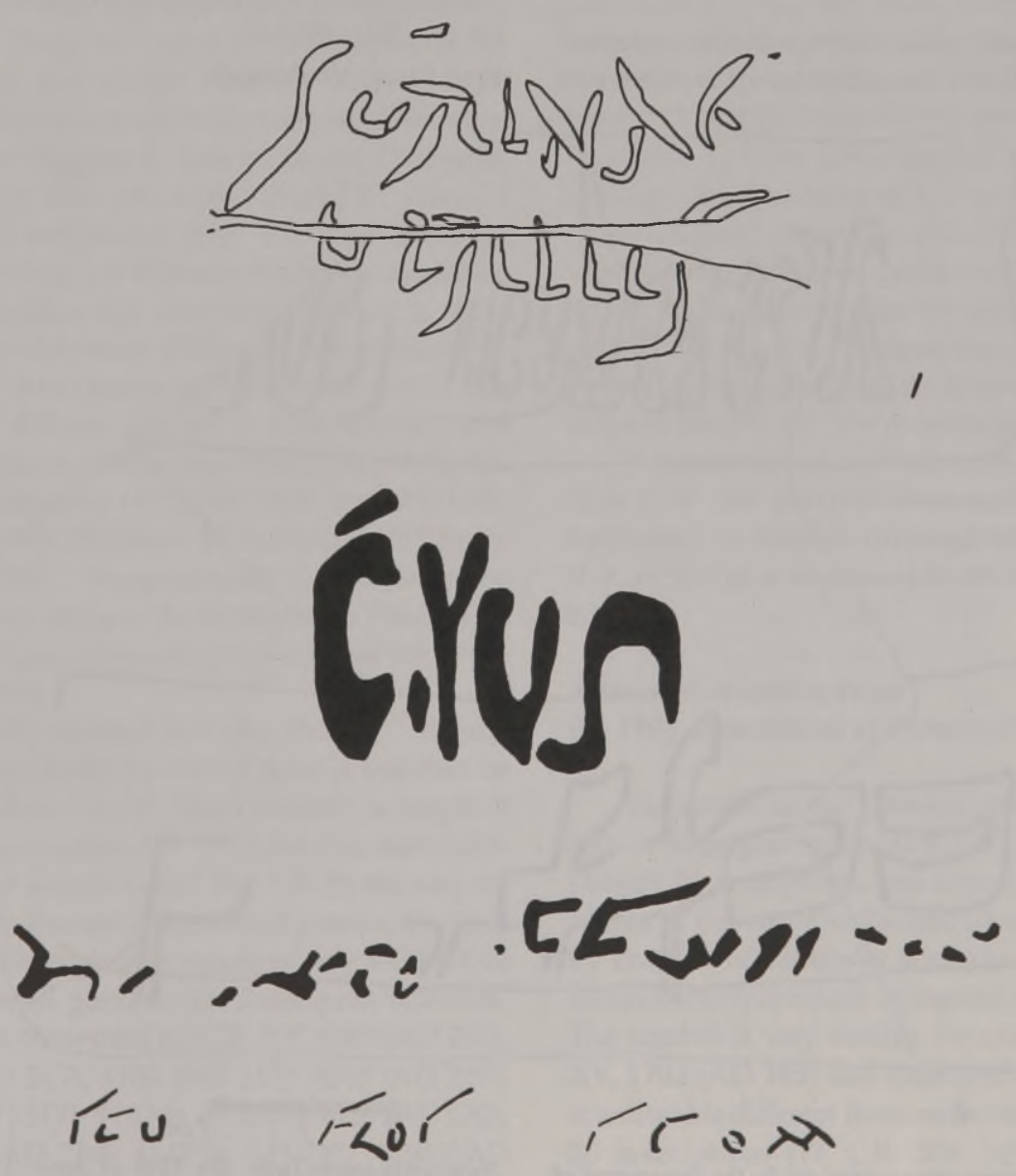
FUNARI, P. P. A. Some Roman inscriptions from Britain: amphora evidences. Rev. do Museu de Arqueologia e Etnologia, S. Paulo, 3: 121-135, 1993.

but the fish sauce or garum. The absence of the word garum, always quoted both in inscriptions and in the literary sources makes it nonsense (cf. Plinius, Naturalis Historia, 31,94: garum nunc e scombro pisce laudatissimus in Carthaginis spartariae ceteriis; socionum id appelatur; Martial,13,102: esperantis adhunc scombri de sanguine Accipe fastosum, munera cara, garum);

7. The use of a Dressel 20 amphora to hold fish sauce would be surprising, taking into account that garum was imported in amphorae and it would not be usual to tranfer it from its original vessel to an used one.

Unfortunately, it is impossible to propose an alternative reading, taking into account the inaccurate drawing available.

\section{An unpublished Dressel 20 painted inscription from Vindolanda}

The Director of the Vindolanda Archaeological Trust, Robin Birley, has submitted to the author two photos of a Dressel 20 Spanish olive-oil amphora found in his 1973 excavations, from the level dated from the begining of the second century $\mathrm{AD}$ (100120). ${ }^{1}$ As the whereabouts of the actual pottery sherd at the moment is unknown, it was only through these photos that it was possible to study these tituli picti. The photographs bear no scale, but perhaps it is suggesting that the pittacium (meaning here a small piece of linen or leather spread with salve, cf. Cels. 3,10 ) in both tituli beta and gama are just $1.6 \times 5.0$ Roman inches, suggesting thus is a probably at a $1: 1$ scale (or otherwise $1: 2$ or 1:1.5). In spite of the faint ink impression, it is possible to propose a roughly sure reading of the dipinto, providing very interesting information on both paleographic and historical grounds.

\section{Description and commentary (FIGURES 3 and 4)}

Titulus beta: $<\mathrm{L}>$ AELIOPTAELI $<$ AN $>$ LVP Titulus gamma: CCXXXII or CCXXIII Cf. CIL XV, 3693-4

Find Place: Vindolanda

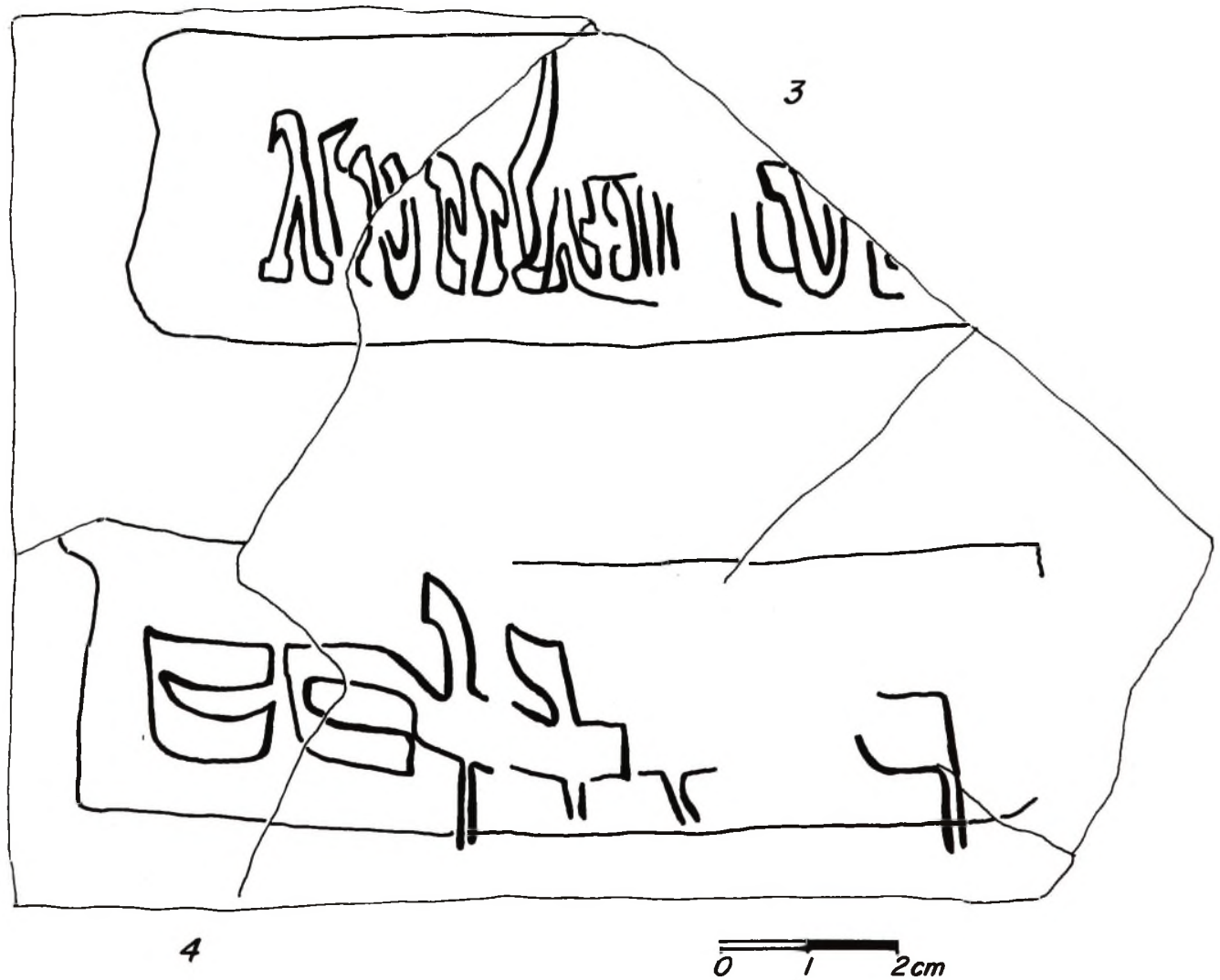

(1) The photographs were carried out by the Department of Newcastle-upon-Tune, the 30th of June, 1975 (no.A Photography and Teaching Aidas Laboratory, University of 
Storage Place: the Vindolanda Archaeological Trust (1973 excavations)

Contextual date: $\mathrm{AD} 100-120$

Other Contextual Dates: AD 154 (CIL XV, 3693)

Control at: Hispalis ? (cf. Rodriguez-Almeida, 1985:224)

The proposed reading of titulus beta is AELI OPT(ati), AELI<AN>(i) LVP<ATI. Some letters are very clearly visible, as A OPTAE, others are probable, as ELI IL LV, and some are almost invisible, as AN P. Dressel published a titulus beta LAELOPTCAESAELLVPATI, referring to a L. Aelius Optatus Caesianus Aelianus Lupatus (as prefers Rodriguez-Almeida, 1984:224) or to four different tradesmen, L. Aelius Aelianus, L. Aelius Caesianus, L. Aelius Lupatus and L. Aelius Optatus (as Bormann in CIL XV, 3993 and Chic 1988:5) dated by a titulus delta $(=\ldots$..ccx.../...secund...h.../ commodo et laterano cos $=\mathrm{AD} 154$ ). This new inscription seems to favour this last interpretation, refering to three partners Optatus, Aelianus and Lupatus, from the same family (Aelii). If the contextual date is right $(\mathrm{AD} 100-120)$, it would indicate that this commercial society had been active for at least 35 years. L. Aelius Optatus (Thévenot, 1952) was also associated with DD. Caecilii Hispitales et Maternus (CIL XV, 3795, at Astigi, nowadays Écija, in Southern Spain), strenghtening the supposition that there were different L. Aelii acting as tradesmen. Although most associations of two or more partners use ET (and) to note that there are different persons, it is not impossible to suppose that they sometimes merely put side by side different names as in $\mathrm{C} \mathbb{L} \mathrm{XV}, 3881$ (=c. AD 150), showing SOCIOR(um) HYAC(inthi), ISID(ori), POLLIONIS. Paleographically, it is interesting to note that the shape of the letters is very like the CIL $\mathrm{XV}, 3693$ one, particularly the fact that the letters are very thin.

Titulus gamma has two clear CC letters, followed probably by two or three $\mathrm{X}$ and then by now invisible II or III. The reference to a weight of 233 Roman pounds of olive-oil would be remarkable in a period as early as $\mathrm{AD} 100-120$. By the way, the other 230s Roman pounds tituli gamma, all dated from the 140 s onwards, represent only $3.45 \%$ of all known tituli gamma (cf. Rodriguez-Almeida, 1984:204; these tituli are CIL XV, 4099 (AD 216), 4100 (AD 217), 4103 (AD 217), 4105 (AD 217), 4106 ( $\mathrm{AD} 217), 4107$ (c. $\mathrm{AD} 217$ ), 4120 (AD 230), 4137 (c. $\mathrm{AD} 230$ ), 4142 (c. $\mathrm{AD} 230$ ), 4290 ( $\mathrm{AD}$ 153 ?), 4307 ( $\mathrm{AD} 154$ ), 4348 (AD 160), 4375 ( $\mathrm{AD}$
179), 4377 (AD 179), 4381 (AD 179), 4385 (AD 180), 4387 (AD 190), 4404 (AD 149), 4486 (c. 250 ?). However, we have very few tituli picti from the period between $A D 50$ and $A D$ 140. On paleographic grounds, I would prefer a 230s reading, but the right side of this titulus gamma is too unclear to formulate any outright sure proposal.

\section{Conclusions}

This inscription being date, as it seems to be the case, in the first two decades of the second century $\mathrm{AD}$, it is important for students of olive-oil Dressel 20 amphorae tituli picti for two main reasons:

1. On a paleographic level, it is interesting to compare the shape of the letters and numbers of this inscription with other dated tituli picti. The thin letters are very like mid second-century tituli beta as in CIL XV, 3759 (AD 160) the letters $\mathrm{P}$ and $O$ (FIGURE 5). They are very different from first century tituli but show some letters like another painted inscription from Vindolanda, dated from the AD 90s (Funari, 1991:70-71), as the letter $\mathrm{A}$, while others as $\mathrm{O}$ or $\mathrm{T}$ are very different (FIGURE 6). The same applies to the titulus gamma, for the shape of $\mathrm{CC}$ is very like mid second century inscriptions (FIGURE 7). They are very different from both mid first century and the AD 90s titulus gamma from Vindolanda (FIGURE 8). This means that paleographically there were some important changes in the letters and numbers shape in the late $\mathrm{AD} 90 \mathrm{~s}$ or in the early $\mathrm{AD} 100 \mathrm{~s}$.

2. On the historical level, it must be stressed that it is the earliest association of three tradesmen in Baetica olive-oil transportation, if it is really a partnership of three Roman citizens.

\section{A Dressel 20 titulus from the 1959 excavations at Catterick}

The titulus on the Caterick sherd is labelled alfa in Rodriguez-Almeida's (1972) scheme for Dressel 20 inscriptions, and relates to the empty weight of the vessel in Roman pounds (FIGURE 9). The style of this titulus is similar to typological features noted previously on Antonine inscriptions. The number is very similar, for example, to $\mathrm{CIL}$ $\mathrm{XV}, 3703$ (AD 149) and 3224 (AD 149), while it is noticeable different from earlier known Dressel 20 inscriptions (cf. CIL XV, 3696, AD 91). Unfortunately, we do not have enough later (that 
FUNARI, P. P. A. Some Roman inscriptions from Britain: amphora evidences. Rev. do Museu de Arqueologia e Etnologia, S. Paulo, 3: 121-135, 1993.
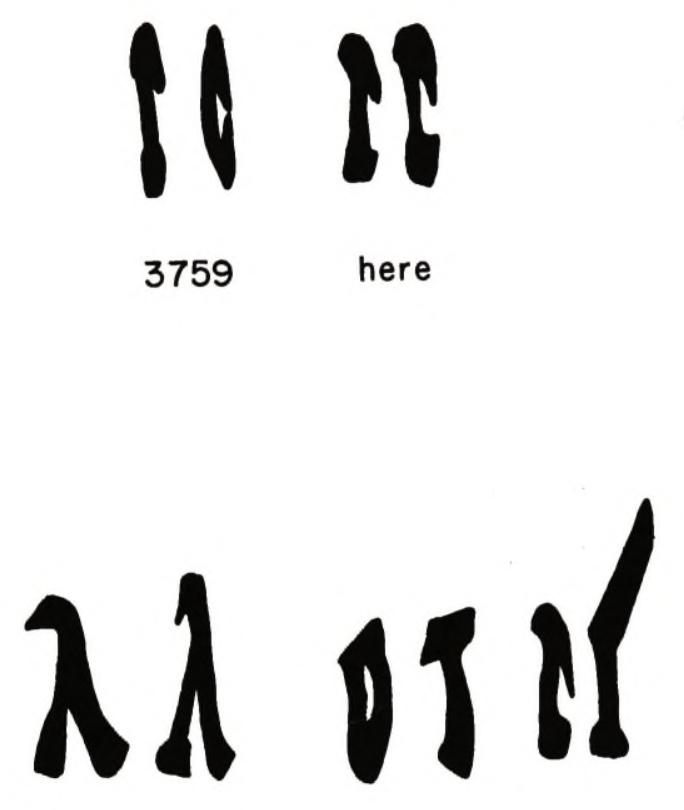

6
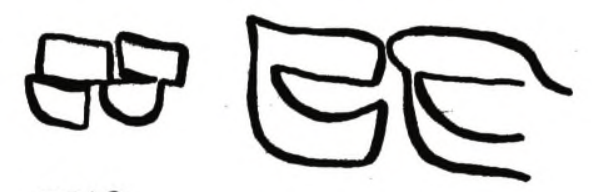

\section{0}




$$
\text { to. }
$$


FUNARI, P. P. A. Some Roman inscriptions from Britain: amphora evidences. Rev. do Museu de Arqueologia e Etnologia, S. Paulo, 3: 121-135, 1993.

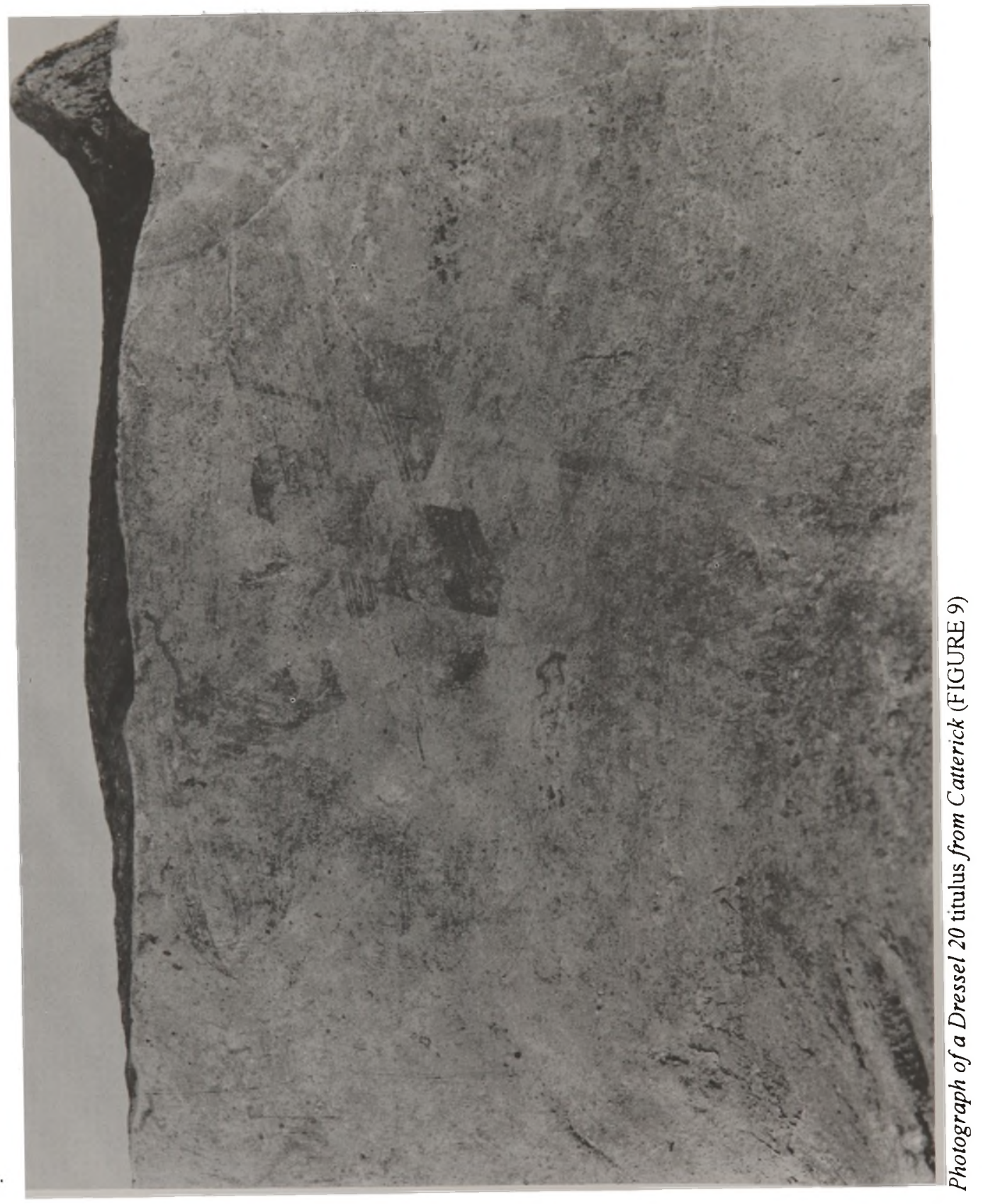


FUNARI, P. P. A. Some Roman inscriptions from Britain: amphora evidences. Rev. do Museu de Arqueologia e Etnologia, S. Paulo, 3: 121-135, 1993.

is third century $\mathrm{AD}$ ) published examples to be confident that it is not of a later date, but is seems to me that the Catterick inscription is so closely like the known mid second century $\mathrm{AD}$ examples quoted above, taht it can be supposed to be of this date.

On the reading, there are two possibilities. The first one could be XCVI (between 96 and 99), for it may be possible to see the apex of a V, which would then make it like CIL XV, 4491, nos. 86 and 70 (cf. FIGURE 10). However, I should prefer instead the analogy with CIL XV, 4491 no. 41 in what relates to the first I and to 3724,3758 nos. 68 to 70 in what relates to the second I (cf.FIGURE 11). This solution seem to me better on paleographic grounds. The weight of the vessel could well be 95-99 and, in this case, I should suggest the weight of the olive-oil would be c. 216 (cf. Funari, 1987:218-9, A 2 and 5). But it could also be alfa $=92$ and gamma $=192$ (Funari, 1987:218-9, D

3 ). If we had the handle it would be easier to decide between $\mathrm{D} 3$ and $\mathrm{A} 5$, the former being longer and the latter showing a more rounded shape.

\section{Amphora inscription}

Some time ago, I had access to photographs of painted inscriptions on a long-neck amphora. Some time later, they were published, with different readings in Britannia (1990:370) and The Antiquaries Journal (1989:53-73). Although I was consulted by Mark Hassal on the inscription and he refers to some of my comments in his very brief note in Britannia, I think I should address some of the problems relating these tituli. I will not discuss here the contentious questions relating the classification of the amphora as Haltern 70 or London 555 and to its origin in Baetica (on these matters, see P.R.Sealey and P.A. Tyers, 1989). I will deal with the inscriptions themselves and the possible contribution their reading can give us in relation to the vessel's type and origin.

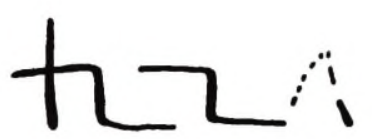

X C

C $\quad$ V I
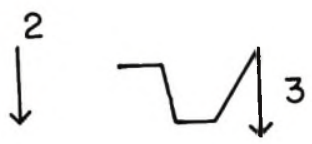

3

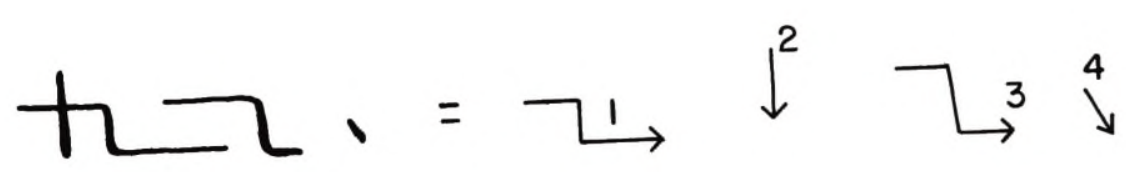

$\times \quad$ C I I 


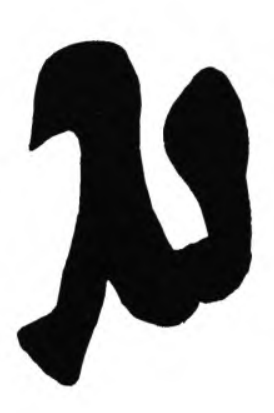

12
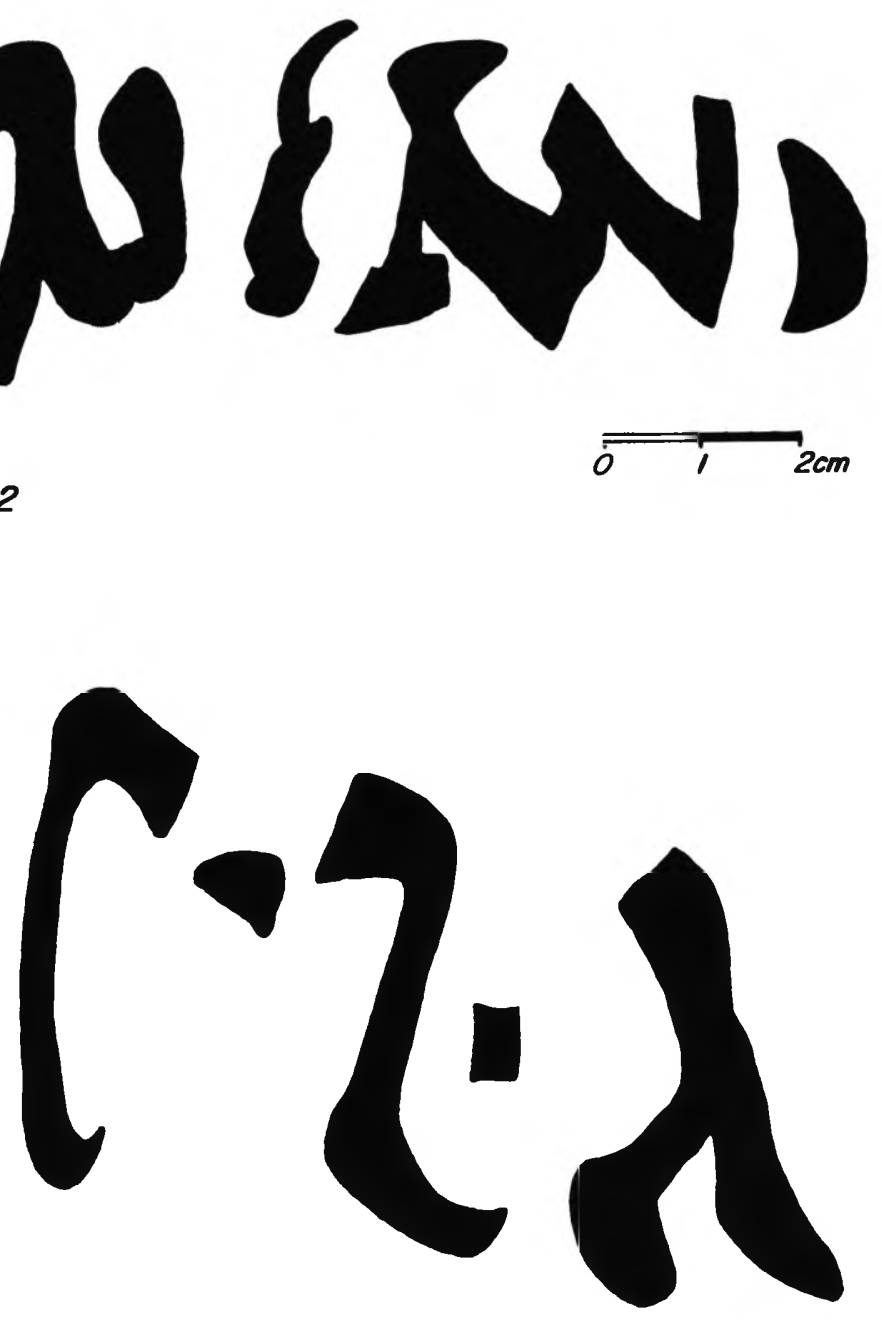

12

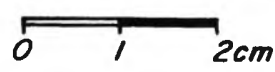

The inscription is composed of five different elements. The disposition of them is a common one in the mid first century $\mathrm{AD}$ amphorae, that is, there are some informations put on the neck and upper body of the vessel, written with capital painted letters, and a perpendicular inscription on the right side of it. The first ones relate in general to the product inside the vessel, its quality and the name of the tradesman charged with the transport of amphorae. The second one relates in general to a name in the genitive case or to a number. In this case, the proposed reading is:

OL/AL/CCL/C.L.A auerni (FIGURE 12) Auerni.

Transcription: OL(iva) AL(ba), CCL, COLOAO

Translation: white olive, $250<$ Roman pounds $>$, transported by COLOAO, controlled by Avernus. 


$$
\lambda_{12}^{13}
$$


FUNARI, P. P. A. Some Roman inscriptions from Britain: amphora evidences. Rev. do Museu de Arqueologia e Etnologia, S. Paulo, 3: 121-135, 1993.

\section{Paleographic analysis}

The shape of the letters is very similar to the fossa aggeris of the castra praetoria's amphorae inscriptions published by Heinrich Dressel in CIL $\mathrm{XV}, 2$ (= before $\mathrm{AD} 50$ ), as well as to the PortVendres II ship wreck material $(=c$. $A D$ 43). If this is true in general terms, it must be stressed that the letters'shape is particularly like some Baetican fish-sauce amphora inscriptions (cf. CIL $\mathrm{XV}, 4720=$ Dressel 10; $4721=$ Dr.9). The most similar related titulus is $\mathrm{CIL} \mathrm{XV,} \mathrm{4802,} \mathrm{found} \mathrm{at}$ the fossa aggeris: the letters $\mathrm{O}, \mathrm{L}$ and $\mathrm{A}$ are very much the same. The letter $R$ is the same as an inscription on a Dressel 20 of c. AD 43 (Colls et alii, 1977: 54, fig.6). The letter C in CCL is the same as CIL. XV, 4733 (=Dr.7) (FIGURE 13). On paleographic grounds alone a Baetican origin and a mid first century date is the most probable. This is in agreement with Sealey and Tyers (1989:69) suggestion about the production of the vessel in Baetica, but their proposed date (AD 55-85) should be reassessed. Indeed, the paleography suggests an earlier date, in agreement with the typology of the vessel (following, in this respect, Beth Richardson's remarks in Britannia, 1990:369).

\section{Interpretation of the inscriptions}

The inscription is composed of two very sure elements and three other which could, even though less clearly, be interpreted with enough probability.

\section{The Roman tria nomina}

In the last horizontal line we have three letters with two stops representing a Roman citizen, probably the mercator or entrepreneur charged of the transportation of the product: C.L.A. Even though we do not have enough elements to know how to develop COLOAO, it could be related to the MO LOCILLI ALEXANDRI inscription (CIL $\mathrm{XV}, 3660-61$, found in the fossa aggeris, on a Dressel 20) and being perhaps the same mercator as in CIL XV, 3662, COLVCILI... (on a Dressel 20 in the fossa aggeris). Even if tria nomina in

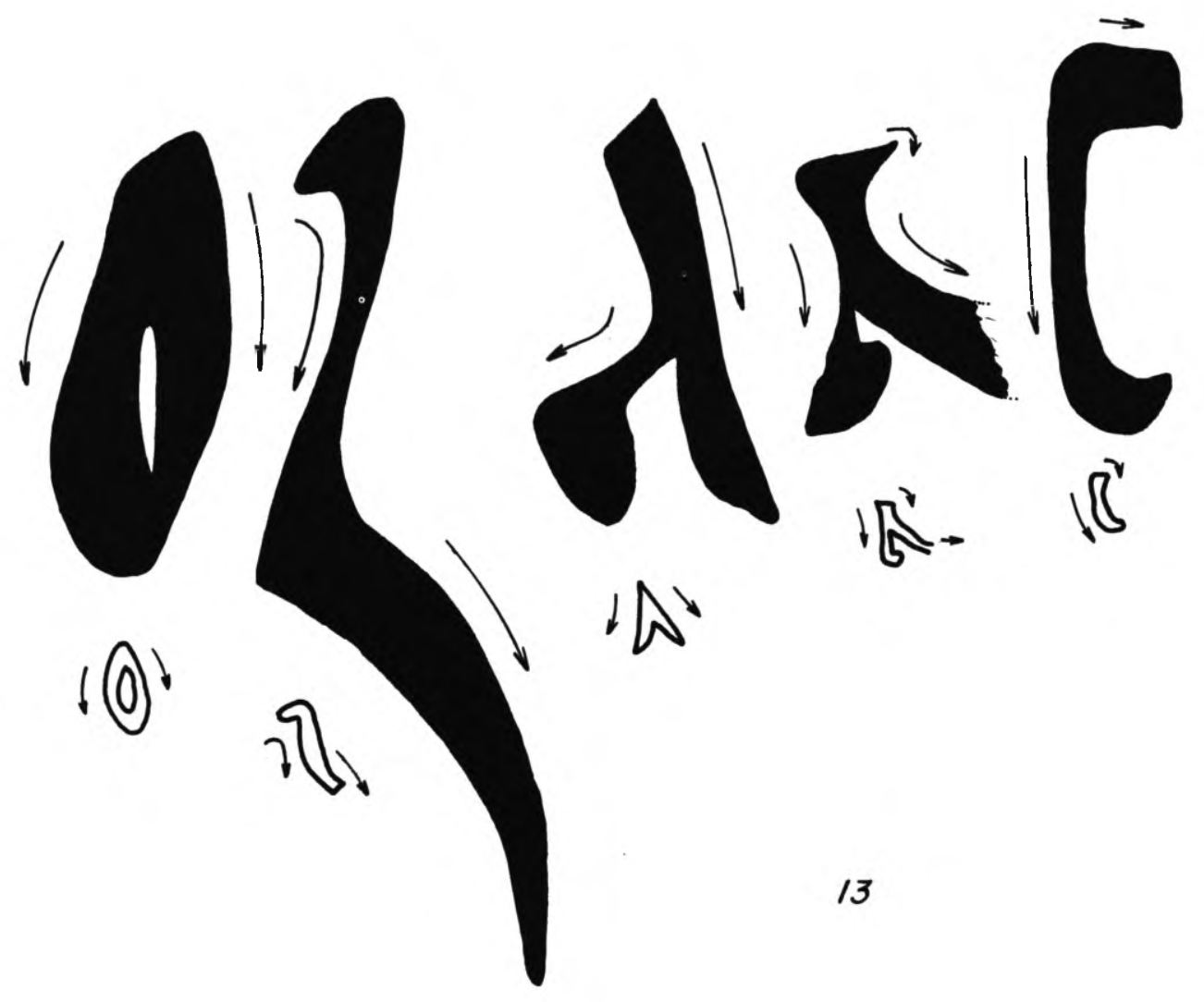


this position are usually developed, we have some examples of abbreviations with three letters, like in CIL XV, 4591 (=Dr. 1), 4691 (=Dr.8), and 4787 (=Dr.21) or in CIL IV, 9442, 9460-61-72, 9531, $9548,9603$.

\section{The number $C C L$}

The number CCL may refer to the number of amphorae or to the weight, possibly of the product inside the vessel, expressed in Roman pounds. There are some examples of very high numbers like this one, such as CCCCXXV in CIL XV, 4733, CCCXXIIX in 4740, and CCCC in CIL IV, 9379. As 250 Roman pounds means $81.85 \mathrm{~kg}$., thought to be too much for the weight of the product inside the vessel (and even to the weight of the vessel and the product), Mark Hassal (in Britannia, 1990: 370) proposed that it could refer to cyathi, meaning thus some 11.4 litres. This interpretation, if it apparently solves the problem of a high number refering to Roman pounds, is however problematic for different reasons: as far as amphora inscriptions enable us to judge, the Romans did not use to use measures of volume. This is particularly true in relation to preserves, an inevitable mix of liquid and solid materials, as is here the case with olives. Perhaps the best explanation to this, as well as other, very high numbers on amphorae should be that it refers to some kind of reckoning of vessels, as suggested by a Dressel 6 first century inscription pridus novemres uinum in cuneum amfurae CCCLXXXXILX (388 amphorae were put in the store room in the 12 th of november) (Funari, 1987:51).

\section{The first two lines}

The first line is very clearly $\mathrm{OL}$ and the second could be A or AL. It could then be OLIVA ALBA, as in CIL XV, 4802 (=fossa aggeris) a suggestion strenghtened by two facts:

1. Columella (XII,49) refers fo white olives prepared and put inside the amphora. This possibility is enhanced by the fact that Columella's prescription includes must, for amphorae of shapes like this one (London 555 or Haltern 70) were used to carry wine. This could explain why a wine amphora, or an amphora of similar shape, could carry olives. Indeed, we have Haltern 70 amphorae with oliva nigra ex defr(ucto) found at Vindonissa and Oberaden and I agree with D. Colls (et alii, 1977:88) that "les olives en question auront été mises, en fait, dans des amphores à defrutum, c'est-à-dire dans des amphores à vin". Even though olive is not a common product, it is well attested not only in Latin inscriptions but also in Greek (CIL XV, 4871, eléas $=$ olives) and Hebrew (CIL XV, 4898), strenghtening the likelihood of this intepretation;

2. It is possible that the amphora quoted by Dressel in CIL XV, 4802 is of the same type for, as he wrote, the inscription was in collo amphorae fractae quod formam habet infundibulo similem. The word infundibulum ("tundish") could refer to the odd shape of this amphora (the inscription refers to oliva $<a>l b(a) / d u l(c i s)$.

We do not have other $A L$ known junctions but it was a common practice to describe the product in abbreviated inscriptions (cf. MAL in CIL XV, 4783, for mala). It could also be OLIVA ANNO, the very long final stroke to the bottom being a mark difficulting adulteration (FIGURE 14). That is, this would rule out the change to AA (= "with two years") or AAA (="with three years") and so on. But, as Columella states hac conditura oliuis toto anno commode uteris. If $\mathrm{OL}$ is to be interpreted as oliua (or as oleum, for that matter), it would be better used before one year. If so, why would someone put the number of years in an olive amphora, if it could not be used after more than one? The only other inscription that I know of this type with only one A is CIL IV, 9338: TAR/A/C.C.R.In this case, however, it refers to wine, a product the older the better. It seems thus much more probable the reading OL(iua) $\mathrm{AL}$ (ba).

\section{The vertical inscription}

We can distinguish surely three letters: ERN as well as a first letter A (FIGURE 15).The last I is similar to CIL XV, 4731 (Dr.10) and the proposed $A V$ would be an $A$ with a V like $C I L$ $X V, 4736$. In this case, it should be a name in the genetive case, generally interpreted as a servile name (cf. CIL XV, 4732 = Romani; 4736, Maced Quo...; $4737=$ Domestic...; $4741=$ Hesperi D...; 


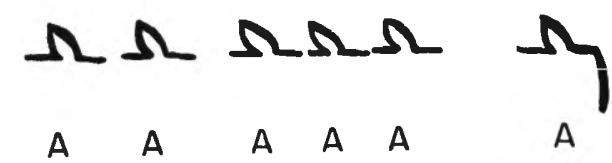

NERNI

$\widehat{A V E R N I}$ $4753=\ldots$...ti Lucil S(erui); $4756=$ Crani). If so, I would suggest the name Auernus.

\section{Conclusion}

These inscriptions are interesting for different reasons. The Dressel 20 inscription from Alcester, found far from the main coastal settlements, implies that these huge amphorae were transported over Roman roads for some miles inside the country (Smith, 1978). Although Alcester was related to a Roman military settlement network dating from the early days of the Conquest (Frere, 1975:291), and it was certainly not an autonomous native centre, it probably developed as a Romanobritish settlement. If so, the importation of oliveoil not only in Alcester but also in Vindolanda and Catterick was an interesting feature (Davies 1971), stressing, once again, the cultural significance of the consumption of Roman products and confirming Professor Frere's (1975:322) suggestion that "in provinces containing armies, the government was more concerned than in unarmed provinces to create a civilized "hinterland", or at least that in these provinces it possessed ( in the Army) the means of materializing its policy". Consumption of Spanish olive-oil and olives was thus much more than good taste, it was the materalization of a state-sponsored civilized lifestyle.

\section{Acknowledgements}

I owe thanks to the following colleagues: Robin Birley, Mark Hassal, Roger Tomlin, and David Williams. The ideas presented here are my own and for which I alone am therefore responsible.

FUNARI, P. P. A. Some Roman inscriptions from Britain: amphora evidences. Rev. do Museu de Arqueologia e Etnologia, S. Paulo, 3: 121-135, 1993.

ABSTRACT: The paper aims at the publication and analysis of some painted inscriptions on amphorae found in Britain. They are studied and discussed in terms of their historic and paleographic characteristics. The author concludes with a brief discussion of Spanish olive-oil and olive consumption as the materialization of a state-sponsored lifestyle.

UNITERMS: Latin inscriptions - Roman amphorae - Olive-oil consumption. 
FUNARI, P. P. A. Some Roman inscriptions from Britain: amphora evidences. Rev. do Museu de Arqueologia e Etnologia, S. Paulo, 3: 121-135, 1993.

\section{References}

CHIC-GARCÍA, G. (1988) Epigrafia anfórica de la Bética II.Universidad de Sevilla, Seville.

COLLS, D. et alii (1977) L'épave Port-Vendres II et le commerce de la Bétique à l'époque de Claude. De Boccard, Paris.

DAVIES, R.W. (1971) The Roman military diet. Britannia, 2:122-142.

DRESSEL, H. (1978) Saggi sull'instrumentum domesticum. Eucoop, Perugia.

- (1889) Corpus inscriptionum latinarum (CIL), volumen $X V$. Akademie Verlag, Rome.

FRERE, S.S. (1975) Verulamium and the towns of Britannia. Aufstieg und Niedergang des roemischen Reiches, II,3. Prinzipat, Berlin: 290-322.

FUNARI, P.P.A (1987) Estudo tipológico das ânforas Béticas (Dressel 20) de ca. 149 d.C., Dédalo, 25, 209-233.

-. (1987) Em torno da ânfora: a terminologia latina dos vasos recipientes. N.F.Pinto; J.L.Brandão(Eds.) Cultura Clássica em Debate, Belo Horizonte, UFMG/CNPq/SBEC: 51-61.

- (1991) Dressel 20 amphora inscriptions found at Vindolanda: the reading of the unpublished evidence. V.A. Maxfield; M.J.Dobson (Eds.) Roman Frontier Studies
1989. University of Exeter Press Exeter. 65-72.

HAMP, E.P. (1975) Social gradience in British spoken Latin. Britannia, 6: 150-162.

RODRÍGUEZ-ALMEIDA, E. (1972) Novedades de epigrafia anforaria del Monte Testaccio. Collection de l'École Française de Rome, 10, 107-242.

- (1979) Monte Testaccio: i mercatores dell'olio della Betica, Mélanges del'École Française de Rome, 91: $874-$ 975.

- . (1984) Il monte Testaccio. Quasar, Rome.

SEALEY, P.R; TYERS, P.A (1989) Olives from Roman Spain: a unique amphora found in British waters, The Antiquaries Journal, LXIX, I: 53-73.

SMITH, W.P. (1978)Map of Roman Britain, The ordnance survey.

THÉVENOT, E. (1952) Una familia de negociantes en aceite establecida en la Bética en el siglo II: los Aeslii Optati. Archivo Español de Arqueologia, 25, 223-231.

TOMLIN, R.S.O. (1993) Personal letter to the author. Wolfson College, Oxford.

ZEVI, F. (1966) Appunti sulle anfore romane. Archeologia Classica, 17: 208-247.

Recebido para publicação em 22 de junho de 1993. 